\title{
Retrospective analysis of mature cystic teratomas in a single center and review of the literature
}

\section{Matür kistik teratomlarn tek bir merkezde retrospektif olarak incelenmesi ve literatürün gözden geçirilmesi}

\author{
(1) Çiğgdem Yayla Abide, (1) Evrim Bostancı Ergen \\ İstanbul Zeynep Kamil Women and Children's Diseases Training and Research Hospital, Clinic of Obstetrics and Gynecology, İstanbul, Turkey
}

\begin{abstract}
Objective: The aim af this study is to evaluate patients with mature cystic teratomas (MCT) with regard to the view of updated knowledge using our retrospective findings.

Materials and Methods: This was a retrospective study and included a total of 306 patients from 2013 through 2017 at the İstanbul Zeynep Kamil Women and Children's Diseases Training and Research Hospital.

Results: The mean age of the patients was $34.03 \pm 11.98$ years. Thirty (9.8\%) patients were postmenopausal. Torsion was detected in $17(5.6 \%)$ patients. There was a statistically significant relationship between MCT and CA 19-9 levels in our series ( $<<0.01$ ) but no statistically significant correlation was found with other markers.

Conclusion: The possibility of malignancy at postmenopausal ages and in large MCT should not be forgotten. It should be kept in mind that MCT can be seen in unexpected places.

Keywords: Teratoma, CA19-9, adnexal masses

$\ddot{O} z$

Giriş: Bu çalışmanın amacı matür kistik teratom (MKT) tanısı alan olguları, retrospektif bulgularımız ışığında güncellenmiş bilgiye bakış açısından değerlendirmektir.

Gereç ve Yöntemler: Bu, retrospektif bir çalışmadır ve 2013-2017 yllları arasında Zeynep Kamil Kadın ve Çocuk Hastalıkları Eğitim ve Araştırma Hastanesi'nde toplam 306 olgu içermektedir.

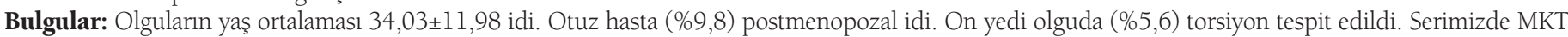
ve CA 19-9 düzeyleri arasında istatistiksel olarak anlamlı bir ilişki vardı ancak diğer belirteçlerle istatistiksel olarak anlamlı korelasyon bulunmadı (p<0,01). Sonuç: Postmenopozal yaş ve büyük MKT’lerde malignite olma ihtimali unutulmamalıdır. MKT’lerin beklenmedik yerlerde görülebileceği unutulmamalıdır. Anahtar Kelimeler: Teratom, CA 19-9, adneksiyal kitle
\end{abstract}

PRECIS: Mature cystic teratomas has association with CA19-9.

\section{Introduction}

Mature cystic teratoma (MCT) is the most common ovarian tumor in women aged 20-30 years and accounts for 95\% of ovarian teratomas $^{(1)}$. Most MCTs are unilateral and benign. Only $10-17 \%$ of cases are bilateral $^{(2)}$. MCTs include tissues of ectodermal (eg., skin, hair follicles, sebaceous glands), mesodermal (eg., muscle, urine) and endodermal origin (eg., lung, gastrointestinal) ${ }^{(3)}$. These tumors have a characteristic ultrasonic image and the specificity of ultrasound is 98-
$100 \%{ }^{(4,5)}$. Malignant transformation is detected in $0.17-2 \%$ of MCTs. When it occurs, the most common is squamous cell carcinoma $^{(6)}$. Risk factors for malignancy, age over 45 years, tumor size $10 \mathrm{~cm}$ and larger, rapid growth, and imaging findings (eg., low resistance tumor flow in Doppler) ${ }^{(2,7)}$. Early diagnosis and treatment of malignant transformation of MCT is very important because 5 -year survival is only $15-30 \%{ }^{(8)}$. We retrospectively analyzed preoperative, postoperative outcomes, and the clinicopathologic characteristics of mature cystic teratomas of the ovary at our institution.

Address for Correspondence/Yazışma Adresi: Evrim Bostancı Ergen, MD,

İstanbul Zeynep Kamil Women and Children's Diseases Training and Research Hospital, Clinic of Obstetrics and Gynecology, İstanbul, Turkey

Phone: +90 5056179623 E-mail: evrimbostanc6666@gmail.com ORCID ID: orcid.org/0000-0002-1634-6781

Received/Geliș Tarihi: 13.01.2018 Accepted/Kabul Tarihi: 18.03.2018

${ }^{\oplus}$ Copyright 2018 by Turkish Society of Obstetrics and Gynecology

Turkish Journal of Obstetrics and Gynecology published by Galenos Publishing House 


\section{Materials and Methods}

This was a retrospective study of all MCTs from 2013 through 2017. The data were obtained from the hospital database of İstanbul Zeynep Kamil Women and Children's Diseases Training and Research Hospital. It included a total of 306 cases. Data regarding age, size, laterality, gross morphologic features, levels of tumor markers alpha fetoprotein (AFP), cancer antigen (CA) 19-9, CA 15-3, carcinoembryonic antigen (CEA), and CA 125, complications, and surgery performed were retrieved from the hospital archives. A laparoscopic approach was preferred for patients who had no contraindications for laparoscopic surgery such as cardiac or pulmonary diseases, and no contraindications for being placed in the lithotomy position, but mainly the surgeon determined which surgery was to be performed.

\section{Statistical Analysis}

The IBM SPSS Statistics 22.0 program was used for the statistical analyses. When the study data were evaluated, the relationships between descriptive statistical methods (mean, standard deviation) was used. Besides these, Student's t-test was used for the comparison of two groups with normal distribution, and Spearman's correlation analysis was used to examine parameters without normal distribution. The chi-square test, Fisher's exact test, and Yates's continuity correction test were used for the comparison of qualitative data. Significance was assessed at $\mathrm{p}<0.05$ level.

\section{Results}

The mean age of the patients was $34.03 \pm 11.98$ years. Thirty patients $(9.8 \%)$ were postmenopausal. The symptoms of the patients and the imaging methods used can be seen in Table 1. Torsion was detected in 17 (5.6\%) patients. No cyst rupture was observed in any of the patients. Cyst diameters ranged from 1 to $20 \mathrm{~cm}$ with a mean of $6.68 \pm 6.0 \mathrm{~cm}$. The mean CA 125 level was $22.96 \pm 15.5 \mathrm{U} / \mathrm{mL}$, the mean CA 19-9 level was $71.11 \pm 17.8 \mathrm{U} / \mathrm{mL}$, the mean CA $15-3$ level was $13.97 \pm 13.5$ $\mathrm{U} / \mathrm{mL}$, the mean CEA level $1.39 \pm 1.09 \mathrm{ng} / \mathrm{mL}$, and the mean AFP level was $177.32 \pm 1.9 \mathrm{ng} / \mathrm{mL}$. The normal values for CA 125 is 0 to $35 \mathrm{U} / \mathrm{mL}$. The reference range of serum CA 15-3 is less than $30 \mathrm{U} / \mathrm{mL}$. The reference range of serum CA 19-9 is less than $37 \mathrm{U} / \mathrm{mL}$. The normal range for CEA in an adult non-smoker is $<2.5 \mathrm{ng} / \mathrm{mL}$, and for a smoker it is $<5.0 \mathrm{ng} / \mathrm{mL}$. An AFP level of less than $10 \mathrm{ng} / \mathrm{mL}$ is normal for adults. There was a statistically significant correlation between cyst diameter and CA 19-9 $(\mathrm{p}<0.01)$. As the diameter of the cyst increased, CA 19-9 level also increased. There was no statistically significant correlation between cyst diameter and other marker levels ( $p>0.05$ ). When the distribution of localization was examined, 25 (8.2\%) patients had bilateral localization and 281 (91.8\%) had unilateral localization. Laparoscopic surgery was performed in $57.8 \%(\mathrm{n}=177)$ of patients. In $19(6.2 \%)$ patients, cyst rupture was detected during surgery, but none of the patients had chemical peritonitis in the post-operative period.
Abundant lavage was applied to patients in whom rupture had occurred. Ninety-one cases (29.7\%) were frozen and 9 cases $(2.9 \%)$ were malignant. Three were reported as immature

Table 1. Symptoms and imaging methods of the patients

$\begin{array}{llll}\text { Symptoms } & \text { Abdominal pain } & \text { n } & \text { \% } \\ & \text { Abnormal uterine bleeding } & 61 & 38.2 \\ & \text { Incidental } & 123 & 40.2 \\ & \text { Postmenopausal bleeding } & 3 & 1 \\ & \text { Mass in labium majus } & 1 & 0.3 \\ & \text { Mass in vagina } & 1 & 0.3 \\ \text { Imaging methods } & \text { MRI } & 32 & 10.5 \\ & \text { USG } & 274 & 89.5\end{array}$

MRI: Magnetic resonance imaging, USG: Ultrasonography

Table 2. Localization of mature cystic teratomas and summary of the surgical procedure utilization

\begin{tabular}{|c|c|c|c|}
\hline & & $\mathbf{n}$ & $\%$ \\
\hline \multirow[t]{6}{*}{ Location } & Bilateral & 25 & 8.2 \\
\hline & Unilateral & 281 & 91.8 \\
\hline & Right & 133 & 43.5 \\
\hline & Left & 146 & 47.7 \\
\hline & Labium majus & 1 & 0.3 \\
\hline & Vagina & 1 & 0.3 \\
\hline \multirow[t]{4}{*}{ Surgery } & Laparoscopy & 177 & 57.8 \\
\hline & Laparotomy & 127 & 41.5 \\
\hline & $\begin{array}{l}\text { Mass excision from labium } \\
\text { majus }\end{array}$ & 1 & 0.3 \\
\hline & Mass excision from vagina & 1 & 0.3 \\
\hline \multirow{6}{*}{ Type of surgery } & Cystectomy & 236 & 77.1 \\
\hline & $\begin{array}{l}\text { Hysterectomy, bilateral } \\
\text { salpingo oophorectomy }\end{array}$ & 46 & 15 \\
\hline & $\begin{array}{l}\text { Cystectomy, salpingo } \\
\text { oophorectomy, } \\
\text { omentectomy, bilateral } \\
\text { pelvic and paraaortic } \\
\text { lymphadenectomy }\end{array}$ & 4 & 1.3 \\
\hline & $\begin{array}{l}\text { Hysterectomy bilateral } \\
\text { salpingo oophorectomy, } \\
\text { omentectomy, bilateral } \\
\text { pelvic and paraaortic } \\
\text { lymphadenectomy }\end{array}$ & 5 & 1.6 \\
\hline & Salpingo oophorectomy & 13 & 4.2 \\
\hline & $\begin{array}{l}\text { Hysterectomy unilateral } \\
\text { salpingo oophorectomy }\end{array}$ & 2 & 0.7 \\
\hline
\end{tabular}


teratomas, three as squamous cell carcinoma, two as yolk sac tumor, and one as adenocarcinoma. The location of the MCTs and summary of the surgical procedures is presented in Table 2 . The mean postoperative hospital stay was $1.89 \pm 1.06$ days. Six (2\%) patients had recurrence after 1 year. A dermoid cyst had been discovered during cesarean section in 8 patients.

\section{Discussion}

MCTs are usually diagnosed at reproductive ages and treatment is surgical. In this study, we observed an association with CA 19-9 and MCT, and we present 2 cases of MCT in unusual locations. Consistent with the literature, the mean age in our study was $34.03 \pm 11.98$ years. In previous studies, it was found to present most commonly between the ages of 20-30 years ${ }^{(9)}$. In our study, we found that $91.8 \%$ of the MCTs were unilateral and more frequent on the left side $(47.7 \%)$. The literature is unanimous with regards the unilaterality of the tumors, and there is no consensus on the right and left dominance. Some studies reported them more frequently on the right, some on the left ${ }^{(2,10-12)}$. Some $38.2 \%$ of the patients were admitted to hospital with symptoms of pain, and $40.2 \%$ cases were found incidentally. In parallel with the literature, MCTs could be detected in $16.6 \%$ and $75 \%$ of asymptomatic patients during routine physical examination and during any pelvic operations, respevtively ${ }^{(1,13-16)}$. The mean size of tumor was $6.68 \pm 6.0 \mathrm{~cm}$. This is in accordance with previous studies where $60 \%$ of tumors were $5-10 \mathrm{~cm}$ in diameter ${ }^{(10,15-17)}$. Similar to previous studies, in our study, the most common complication of MCT was torsion and its detection rate was 5.6\%. Malignant transformation of MCT was $2.9 \%$. In the literature, malignant transformation is found between 1 and 3\% and torsion rates are between 3.5 and $9.2 \%^{(6,13,14)}$. As supported by the literature, advanced age and tumor size are evaluated as risk factors for malignant transformation ${ }^{(2,7)}$. In our study, the mean diameter of MCTs with malignant transformation was $11.23 \mathrm{~cm}$, and the mean age of patients with MCT with malignant transformation was 47 years. There was a statistically significant relationship between MCTs and CA 19-9 levels in our series $(\mathrm{p}<0.01)$ but no statistically significant correlation was found with other markers. In the literature, Ito ${ }^{(18)}$ reported that MCTs has an association with CA 19-9 levels. However, Chen et al. ${ }^{(19)}$, in contrast to our study, found that Ca 125, CA 153, and AFP together had an association with MCTs. With this study, we also evaluated 2 cases MCT that were rare in terms of their location. A 22-year-old patient presented with a vaginal mass of approximately $11 \mathrm{~cm}$. It was filled with sebum and hair, and was diagnosed as MCT by the pathologists. Vural et al. ${ }^{(20)}$ in 2015 concluded that the presence of vaginal teratoma was rare; only 8 cases have been reported worldwide. Our case was the largest of these cases. In another case, a 44-year-old woman was admitted to our hospital with a sebaceous cyst of about $3 \mathrm{~cm}$ in diameter in the labium majus, which was diagnosed as MCT in the pathology report. The rate of rupture during laparoscopy is very high in MCTs. Approximately 54\% has been detected ${ }^{(21-23)}$. The probability of rupture has been found to be independent of size and location of $\mathrm{MCT}^{(24,25)}$. Cyst rupture was detected during surgery in 19 cases in our series in agreement with these studies. All cases of cyst rupture occurred during laparoscopy. However, we detected no chemical peritonitis postoperatively.

\section{Study Limitations}

The number of patients is small because it is a single-center experience.

\section{Conclusion}

The possibility of malignancy in women of postmenopausal age and in large MCTs should not be forgotten. It should be kept in mind that MCTs can be seen in unexpected places such as the eyelids, mouth, vagina, and labia majus. We observed an association with CA 19-9 and MCT, but further studies are needed.

\section{Ethics}

Ethics Committee Approval: This is a retrospective study. Informed Consent: Consent form was filled out by all participants.

Peer-review: External and internal peer-reviewed.

\section{Authorship Contributions}

Surgical and Medical Practices: E.B.E., Ç.Y.A., Concept: Ç.Y.A., Design: Ç.Y.A., Data Collection or Processing: Ç.Y.A., Analysis or Interpretation: E.B.E., Literature Search: E.B.E., Writing: E.B.E. Conflict of Interest: No conflict of interest was declared by the authors.

Financial Disclosure: The authors declared that this study received no financial support.

\section{References}

1. Ayhan A, Bukulmez O, Genc C, Karamursel BS, Ayhan A. Mature cystic teratomas of the ovary: case series from one institution over 34 years. Eur J Obstet Gynecol Reprod Biol 2000;88:153-7.

2. Hackethal A, Brueggmann D, Bohlmann MK, Franke FE, Tinneberg HR, Münstedt K. Squamous-cell carcinoma in mature cystic teratoma of the ovary: systematic review and analysis of published data. Lancet Oncol 2008;9:1173-80.

3. DiSaia PJ, Creasman WT. Germ cell, stromal and other ovarian tumors. In: Clinical Gynecologic Oncology, 7th. Mosby-Elsevier; 2007. p. 381

4. Patel MD, Feldstein VA, Lipson SD, Chen DC, Filly RA. Cystic teratomas of the ovary: diagnostic value of sonography. AJR Am J Roentgenol 1998;171:1061-5.

5. Tongsong T, Luewan S, Phadungkiatwattana P, Neeyalavira V, Wanapirak C, Khunamornpong S, et al. Pattern recognition using transabdominal ultrasound to diagnose ovarian mature cystic teratoma. Int J Gynaecol Obstet 2008;103:99-104.

6. Chiang AJ, Victor La, Peng J, Yu KJ, Teng NN. Squamous cell carcinoma arising from mature cystic teratoma of the ovary. Int J Gynecol Cancer 2011;21:466-74.

7. Dos Santos L, Mok E, Iasonos A, Park K, Soslow RA, Aghajanian C, et al. Squamous cell carcinoma arising in mature cystic teratoma of 
the ovary: a case series and review of the literature. Gynecol Oncol 2007;105:321-4.

8. Park JY, Kim DY, Kim JH, Kim YM, Kim YT, Nam JH. Malignant transformation of mature cystic teratoma of the ovary: experience at a single institution. Eur J Obstet Gynecol Reprod Biol 2008;141:1738.

9. Lakkis WG, Martin MC, Gelfand MM. Benign cystic teratoma of the ovary: a 6-year review. Can J Surg 1985;28:444-6

10. Ismail RS. An evaluation of incidence of right-sided ovarian cystic teratoma visualized on sonograms. JDMS 2005;21:336-42.

11. Chun S, Jeon GH, Cho HJ, Ji YI. Comparison between incidence of right and left-sided ovarian cystic teratoma. J Reprod Endocrinol 2012;4:43-8.

12. Khan MM, Sharif N, Ahmad S. Morphological spectrum of mature ovarian teratoma. Gomal Journal of Medical Sciences 2014;12:7680.

13. Wu RT, Torng PL, Chang DY, Chen CK, Chen RJ, Lin MC, et al. Mature cystic teratoma of the ovary: a clinicopathologic study of 283 cases. Zhonghua Yi Xue Za Zhi (Taipei ) 1996;58:269-74

14. Hursitoglu BS, Demirtas GS, Demirtas O, Akman L, Yilmaz H. A clinico-pathological evaluation of 194 patients with ovarian teratoma: 7-year experience in a single centre. Ginekol Pol 2013;84:108-11.

15. Papadias K, Kairi-Vassilatou E, Kontogiani-Katsaros K, Argeitis J, Kondis- Pafitis A, Greatsas G. Teratomas of the ovary: a clinicopathological evaluation of 87 patients from one Institution during a 10-year period. Eur J Gynaecol Oncol 2005;26:446-8.

16. Comerci JT Jr, Licciardi F, Bergh PA, Grerori C, Breen JL. Mature cystic teratoma: a clinicopathologic evaluation of 517 cases and review of the literature. Obstet Gynecol 1994;84:22-8.
17. Peterson WF, Prevost EC, Edmunds FT, Hundley JM Jr, Morris FK. Benign cystic teratomas of the ovary: a clinico-statistical study of 1,007 cases with a review of the literature. Am J Obstet Gynecol $1955 ; 70: 368-82$

18. Ito K. CA 19-9 in maturecysticteratoma. Tohoku J Exp Med 1994;172:133-8

19. Chen C, Huang H, Feng YL, Wang LH, Chen L. Diagnostic value of multiple tumor marker detection for mature and immature teratoma of theovary. Ai Zheng 2008;27:92-5.

20. Vural F, Vural B, Paksoy N. Vaginal teratoma: A case report and review of the literatüre. J Obstet Gynaecol 2015;35:757-8.

21. Ulrich U, Keckstein J, Paulus W, Sasse V. Endoscopic surgery for mature teratoma of the ovary. Surg Endosc 1996;10:900-3.

22. Luxman D, Cohen JR, David MP. Laparoscopic conservative removal of ovarian dermoid cysts. J Am Assoc Gynecol Laparosc 1996;3:40911.

23. Campo S, Garcea N. Laparoscopic conservative excision of ovarian dermoid cysts with and without an endobag. J Am Assoc Gynecol Laparosc 1998;5:165-70.

24. Milad MP, Olsen E. Factors that increase the risk of leakage during surgical removal of Benign cystic teratomas. Hum Reprod 1999;14:2264-7.

25. Nezhat C, Kalyoncu S, Nezhat CH, Johnson E, Berlanda N, Nezhat F. Laparoscopic management of ovarian dermoid cysts: ten years experience. JSLS 1999;3:179-84. 